\title{
Mapping ICT Use along the Citrus (Kinnow) Value Chain in Sargodha District, Pakistan
}

\author{
Muhammad Waqar, Rui Gu * and Fengying Nie * \\ Agricultural Information Institute (AII), Chinese Academy of Agricultural Sciences, Haidian, \\ Beijing 100081, China; waqarchughtai@caas.cn \\ * Correspondence: gurui@caas.cn (R.G.); niefengying@caas.cn (F.N.)
}

Received: 15 October 2018; Accepted: 7 December 2018; Published: 12 December 2018

\begin{abstract}
The value chains of fresh fruits and vegetables are sensitive to timeliness and require a quick information flow. Keeping in view its importance, this study has focused on mapping the use of information and communication technologies (ICTs) along the citrus value chain, including information channels being used, factors influencing ICT use, challenges, and weaknesses faced by value chain stakeholders. Cross-sectional data were mainly collected by structured and semi-structured interviews with value chain stakeholders and key informants. The citrus industry is very important for Pakistan as it is the 4th most important export commodity. There are two product flows in the citrus value chain, one is more traditional with abundant intermediaries, in which contractors, commission agents and wholesalers are the main stakeholders, and the other is export-oriented with processors and exporters (P\&Es) as the main stakeholders. It has been noticed that growers are not using ICT extensively at the production stage. Logit analysis has proved that education significantly has influenced ICT use while age has a negative impact on ICT use at the production stage. Mobile usage is quite common at the production stage and intermediary trade; however, the use of the internet is very limited as the majority of intermediaries have lower education. Moreover, both mobile phones and internet are used to a significant extent along the export oriented flow. The results have indicated that there is a vast digital divide among value chain players. Processors and exporters are high ICT users followed by growers and intermediaries. In order to develop an effective information system, all the stakeholders in the chain need to have a certain level of knowledge and expertise of ICT use to improve information use efficiency. This study presents a whole picture of ICT use along the citrus value chain as well as challenges faced by different stakeholders. It also provides suggestions for policymakers to establish an ICT-based information system and enhance ICT adoption at each stage, especially production and intermediary trade, which can further increase growers' market participation and improve market efficiency. In addition, it is necessary to make policies under the value chain framework rather than just focused on one stage or one stakeholder.
\end{abstract}

Keywords: ICT use; citrus; value chain; logit analysis; Sargodha; Pakistan

\section{Introduction}

ICT is an important tool of connectivity and information delivery in the modern era [1]. The Group of Twenty (G-20) Agriculture Ministers' Action Plan 2017 has recognized that ICT is a key and important approach for innovation and sustainable agriculture [2]. ICT use is one of solutions to improve the sustainability of food systems by increasing efficiency, enhancing transparency and creating a network between food chain actors [3].

ICT is also an important component of a value chain (VC) network [4]. ICT serves as a glue to supply chain stakeholders to work together [5]. The ICT usage along the supply chains has 
become a performance enabler and causal factor of competitive advantage [6]. Information is critical in agricultural development as it helps in assessing the trends and shaping decisions [7]. Moreover, the role of ICT is to reduce transaction costs in agriculture by enabling timely and affordable communication [8]. ICT has a strong role along the whole VC until the end consumers [9]. Connecting and creating networks between different actors are also benefits of ICT that can provide opportunities for increasing sustainability [10]. In this context, the internet can provide new opportunities for growers to connect and distribute farm produce directly to the consumers (via e-commerce) [3]. ICT is likely to be especially important for highly perishable food products such as fresh fruits and vegetables that are differentiated and possess varied quality dimensions; are sensitive to timeliness in supply and susceptible to damage in transit; and require a quick response at the supply end [11]. The internet serves a way to organize communities, build interactions and spaces to share the knowledge [12]. These could be in the form of online discussion forums or public information centers. The introduction of "internet plus agriculture" is a China's plan to link the whole agricultural value chain from production to marketing by internet-connected networks [13]. India had linked the growers with markets through IT from 2000-2007, by establishing 6400 internet kiosks (named as e-Choupals) in 38,000 villages of nine Indian states to link 4 million farmers with markets [14]. Information sharing means information sharing between VC actors, governmental organizations, non-governmental organization, and research institutes.

Pakistan is one of the least-connected countries (LCC), ranked 136th for access in the ICT Development Index (IDI) [15]. According to the Pakistan Bureau of Statistics [16], 92\% of households have a mobile phone (96\% in urban areas and $90 \%$ in rural areas). According to the Broad Band Commission [17] 15.5\% individuals using the internet and 24.7\% households have access to the internet. Lack of reliance on ICT in government institutions is a reason that Pakistan is held back from improving its IDI ranking [18]. The CABI (Centre for Agriculture and Bioscience International) published a report on knowledge gaps and ICT prevalence along the citrus value chain (mainly television, mobile phone, and computer) [14]. This report discussed briefly the role of ICT and focused more on the value chain itself. However, with the advent of smartphones and $3 \mathrm{G}$ and $4 \mathrm{G}$ internet technology, the scenario of information system and connectivity has changed in the last decade. Systematic mapping is essential to understand ICT use along the chain, identify the vulnerabilities stakeholders faced, and design effective policies [19]. Hence, there is a need to conduct detailed research about ICT-based VC mapping in Pakistan. The objectives of this study include mapping information channels, level of usage of ICT, and factors influencing ICT use along the value chain. This study also focuses on system weaknesses and challenges at different stages such as production, intermediary trade, and processing and export. The results of this study may serve as a guideline for policymakers to improve system functionality by improving information availability in a sustainable way.

The remainder of the paper is as follows: Section 2 presents the overview of citrus industry in Pakistan and Section 3 describes the methodology used in the study. Section 4 describes the results of the study including general information about respondents, factors influencing ICT use at production stage using logit analysis, and level of use of ICT along the chain. The discussion part describes the current situation of ICT and policy suggestion. Section 5 gives the conclusions of the study.

\section{The Citrus Industry in Pakistan}

Citrus is the most important fruit crop and 4th most important commodity after rice, alcohol, and wheat or meslin flour for Pakistan [20]. Pakistan is the 12th largest citrus producer in the world [21], which is a major source of employment in many citrus producing districts, particularly Sargodha district [22]. Kinnow is one of the citrus fruits and of significant importance in Pakistan as its share in citrus fruit is $89.43 \%$ [23]. It has been reported that the Kinnow exports exceeded 370,000 tons with the worth of 222 million USD in 2017-18 [24].

There are two main product flows along the citrus value chain. One is more traditional with growers, contractors, commission agents and wholesalers as important stakeholders [23]. This kind of 
chain takes up to $80 \%$ of total citrus supply in Sargodha, Pakistan, with characteristics of insufficient traceability and low food safety standards. The other is more modern and export-oriented with growers and processors and exporters (P\&Es) as the main stakeholders. This kind of chain is of high-quality, higher margins and high value-addition, which takes up to $20 \%$ of the total citrus supply. Nowadays, supermarkets have played an increasingly important role in the value chain and they can directly connect producers to consumers [25]. However, the role of supermarkets in Pakistan is much weaker than China and India [26]. Metro cash and carry stores are only operating in big cities like Lahore, Islamabad, and Karachi selling fresh fruits and vegetables [27].

The citrus from Sargodha district is exported to around 40 countries of Gulf, Far-east, Central Asia, Europe, and Africa. The main countries include Afghanistan, Russia, Saudi Arabia, United Arab Emirate (UAE), Indonesia, and Philippine, see Figure 1. For Afghanistan, citrus is always transported in open containers by road, while for other countries, citrus is delivered through reefer containers (cold chains) to Bin Qasim port (Karachi) by road and then shipped to next destinations. The duration of transportation varies according to destinations i.e., 2 days for UAE, 4-6 days for Saudi Arabia and 40 days to Russia.

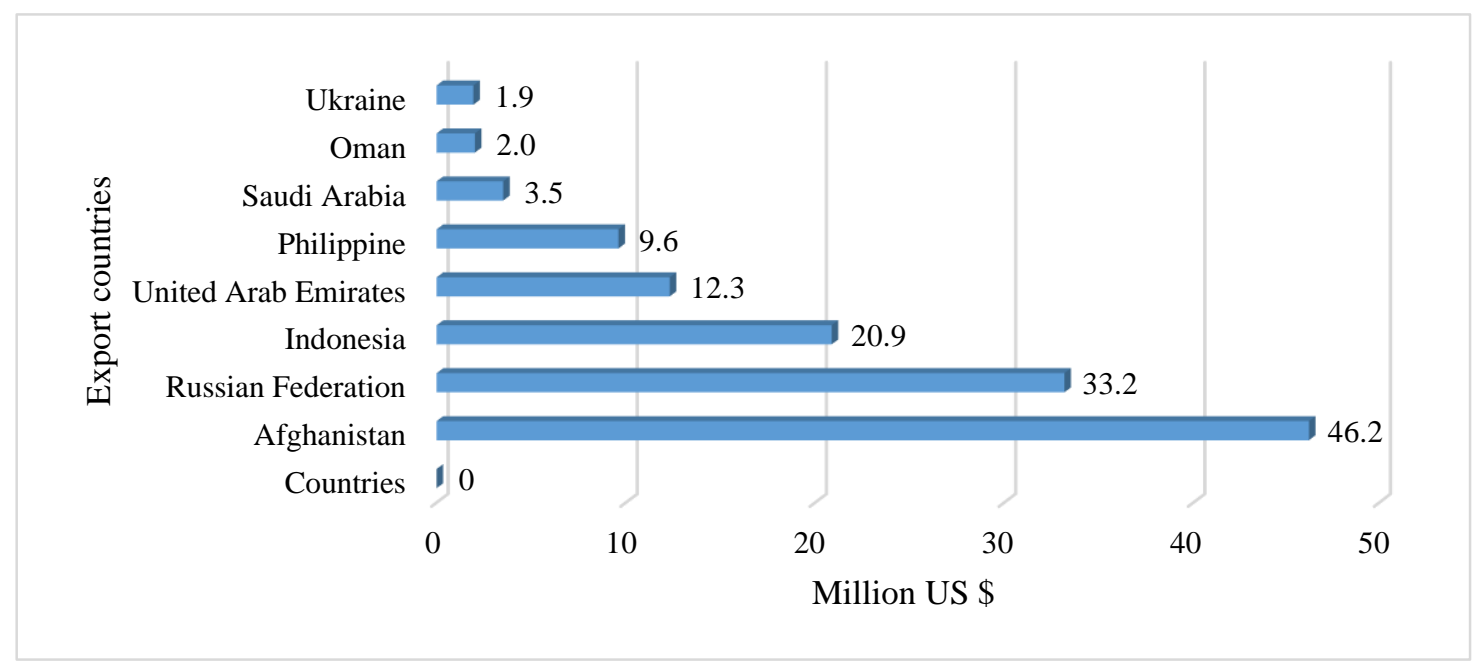

Figure 1. Citrus export from Pakistan to various countries (Data source: UN comtrade, 2016).

Figure 2 shows the geographical supply routes from Sargodha district to other provincial and interprovincial markets. About $40-50 \%$ of the supply of fruit go to Punjab markets, $30-40 \%$ go to Khyber Pakhtunkhwa (Peshawar market) province while 5-10\% go to Sindh and Baluchistan provinces (Karachi and Quetta markets). In an open auction, fruits are sold in these markets to wholesalers and further distributed to other small cities.

Citrus harvesting usually starts from middle of November and lasts till mid-April. A small amount of products (5\%) appear in market in the 2nd half of November, and can receive higher prices. Most of citrus are sold in December (35\%) and January (40\%). February has supplied $15 \%$ of citrus, and March has provided about $5 \%$. However, the temporal mapping of P\&Es vary among growers as most citrus is processed in January and February. 


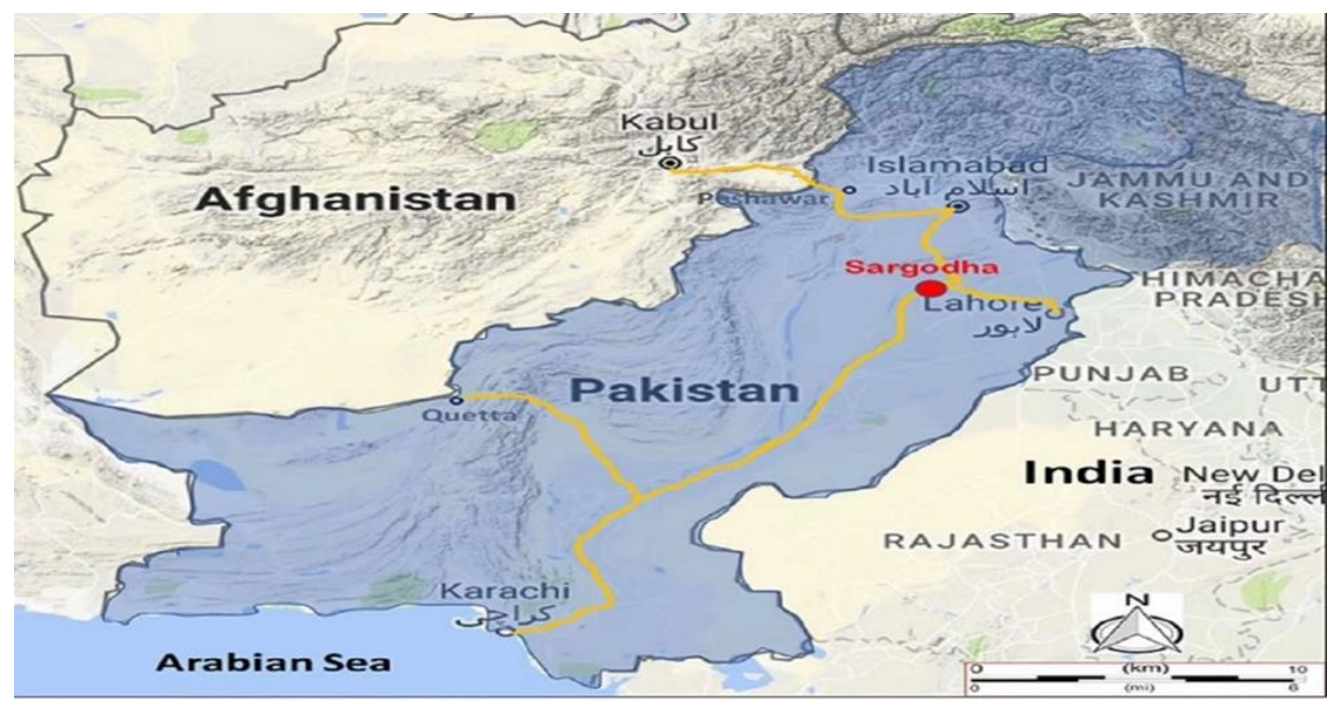

Figure 2. The geographical routs for provincial and interprovincial markets in Pakistan (Source: Prepared by author using ArcGIS).

\section{Methodology}

The cross-sectional data were collected through structured and semi-structured interviews. In the case of structured interviews, five questionnaires were designed, for growers, contractors, commission agents, wholesalers, and P\&Es separately. Data about demographic characteristics, information channels, level of use of ICT, role and activities at each stage were collected. In the case of semi-structured interviews, group discussions were conducted to further collect information from important VC stakeholders and key informants. The participants of group interviews were selected carefully based on their previous experience and education as well as recommendations of key stakeholders, including P\&Es managers, progressive growers, commission agents, and key informants as shown in Table 1. Both structured and semi-structured interviews were conducted with the help of extension officers in local and national languages i.e., Saraiki, Punjabi, and Urdu. The selected respondents were typical and reflect the diversity within each VC stage.

Table 1. The structured and semi-structured interviews with stakeholders.

\begin{tabular}{|c|c|c|}
\hline Data Collection Tools & Stakeholders & Data Collected \\
\hline $\begin{array}{l}\text { Structured Interviews } \\
\text { (Questionnaires) }\end{array}$ & $\begin{array}{l}121 \text { growers, } 25 \text { contractors, } \\
27 \text { commission agents, } 39 \text { wholesalers, } \\
10 \text { processors and exporters (P\&Es) }\end{array}$ & $\begin{array}{l}\text { Demographic characteristics, information } \\
\text { channels, level of information and } \\
\text { communication technologies (ICT) use, } \\
\text { membership of online discussion forums, role } \\
\text { and activities at particular stage, value } \\
\text { addition, production, contracting, marketing } \\
\text { and export system }\end{array}$ \\
\hline $\begin{array}{l}\text { Semi-structured Interviews } \\
\text { (Group interviews) }\end{array}$ & $\begin{array}{l}3 \text { P\&Es managers, } 5 \text { progressive } \\
\text { growers, } 2 \text { commission agents, } \\
2 \text { contractors, key informants } \\
\text { (1 extension officer, } 1 \text { transporter, } \\
1 \text { social worker, } 1 \text { village leader, } \\
1 \text { fruit market president) }\end{array}$ & $\begin{array}{l}\text { Their roles in the citrus value chain, impact of } \\
\text { ICT on business operation, weaknesses and } \\
\text { challenges they faced, suggestions to improve } \\
\text { value chain (VC) efficiency through ICT use }\end{array}$ \\
\hline
\end{tabular}

There are 7 tehsils (subunits of districts) in Sargodha district. Data were collected in 2 randomly selected tehsils i.e., Bhalwal and Sargodha. Subsequently, 4 union councils (subunits of tehsils) from each tehsil and 4 villages from each union council were selected. Around 5 growers were interviewed from each village. Interviews with contractors, commission agents, and wholesalers were conducted in the central fruit and vegetable market. We also visited three best performing enterprises and 7 other randomly selected enterprises from the list prepared by the P\&Es association. They were located in 
different places as shown in Figure 3. The data were collected from July to September 2017. In total, 121 growers, 25 contractors, 27 commission agents, 39 wholesalers and 10 P\&Es were interviewed for this study. The group interviews were conducted with 3 P\&Es managers, 5 progressive growers, 2 commission agents, 2 contractors, 1 extension officer, 1 transporter, 1 social worker, 1 village leader, and 1 fruit market president.

As for the data analysis, firstly, the main operational stages were recognized along the VC, such as production, intermediary trade, and P\&Es. Then, in-depth analysis of ICT use at each stage was done using descriptive statistics and econometric model (Logit model) was built at production stage. Finally, the system deficiencies, challenges, and weaknesses faced by VC stakeholders were identified and discussed.

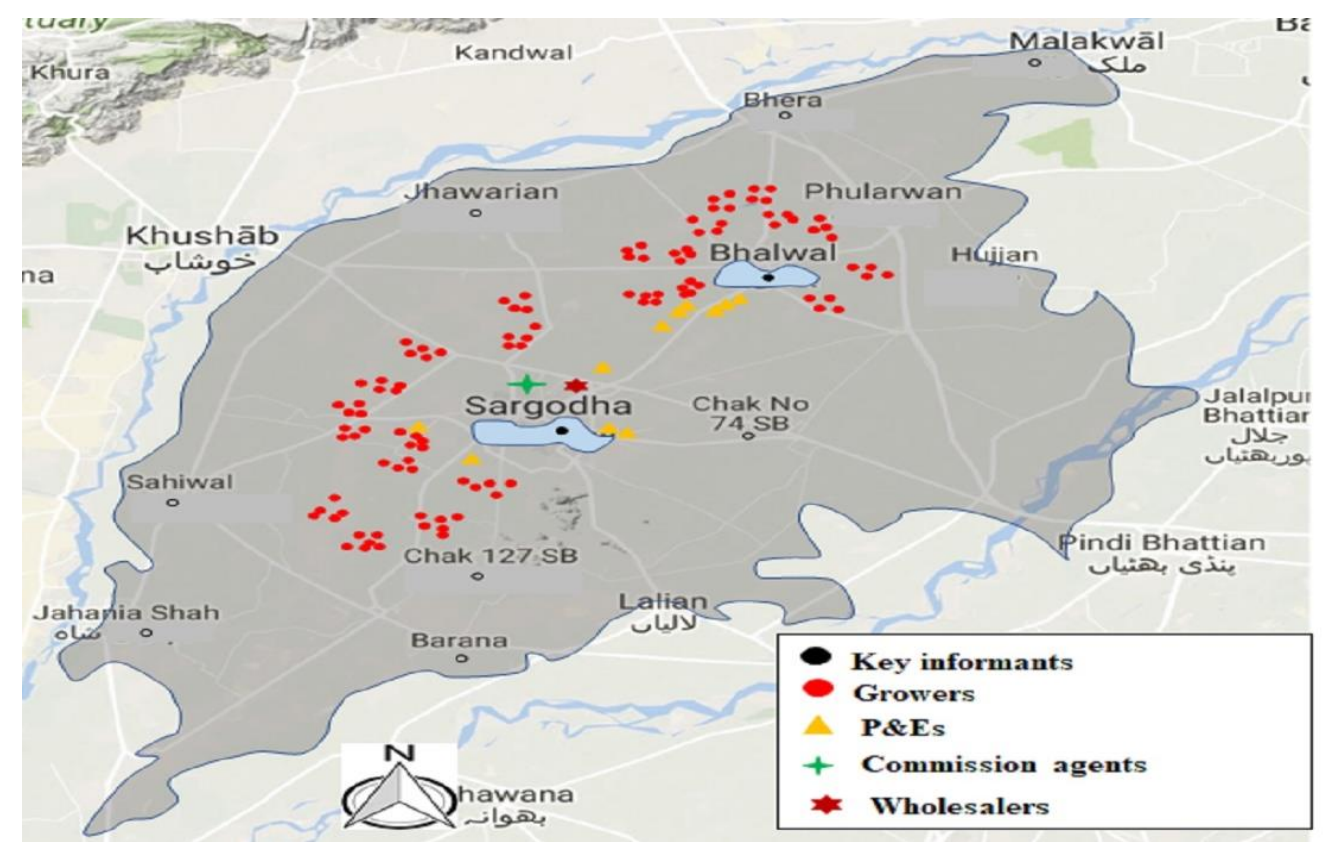

Figure 3. Map of Sargodha district and location of sampling (Source: Prepared by author using ArcGIS).

The logit analysis was used to detect the main factors influencing growers' use of ICT at the production stage.

The logit model based on the logistic distribution is specified as:

$$
\begin{gathered}
\mathrm{P}(y=1 \mid x)=\mathrm{F}(\boldsymbol{x}, \boldsymbol{\beta})=\Lambda\left(\boldsymbol{x}^{\prime} \boldsymbol{\beta}\right)=\frac{\exp \left(x^{\prime} \boldsymbol{\beta}\right)}{1+\exp \left(\boldsymbol{x}^{\prime} \boldsymbol{\beta}\right)} \\
p=\mathrm{P}(y=1 \mid \boldsymbol{x})=\frac{\exp \left(\boldsymbol{x}^{\prime} \boldsymbol{\beta}\right)}{1+\exp \left(\boldsymbol{x}^{\prime} \boldsymbol{\beta}\right)} \text { and } 1-p=\mathrm{P}(y=0 \mid x)=\frac{1}{1+\exp \left(\boldsymbol{x}^{\prime} \boldsymbol{\beta}\right)}
\end{gathered}
$$

The odds ratio is given by:

$$
\frac{p}{1-p}=\exp \left(x^{\prime} \beta\right)
$$

Taking a natural logarithm of Equation (3) we obtain,

$$
\ln \left(\frac{p}{1-p}\right)=x^{\prime} \beta
$$

$p=$ the probability that $y=1$ if the respondent use ICT,

$1-p=$ the probability that $y=0$ if the respondent does not use ICT,

$x=$ vector, the explanatory variables, 
$\beta=$ vector, the coefficients of the explanatory variables, usually estimated by the maximum likelihood procedure, $\ln \left(\frac{p}{1-p}\right)=$ the log odds ratio of the probability that a grower use ICT.

Here, mobile use, internet use, apps use, willingness to invest in ICT, online network membership and ICT's role in price determination were selected as indicators of ICT use; and age, education, farming experience, landholdings, distance from local market, distance from extension office and distance from road were explanatory variables. The expected signs were shown in Table 2.

Table 2. Expected direction of impact of explanatory variables used in logit model.

\begin{tabular}{|c|c|c|c|c|c|c|}
\hline \multirow[t]{2}{*}{ Variables } & \multicolumn{3}{|c|}{$\begin{array}{l}\text { Different Tools to Obtain } \\
\text { Agricultural Information }\end{array}$} & \multirow{2}{*}{$\begin{array}{c}\text { Willingness } \\
\text { to Invest in } \\
\text { ICT }\end{array}$} & \multirow{2}{*}{$\begin{array}{c}\text { Online } \\
\text { Network } \\
\text { Membership }\end{array}$} & \multirow{2}{*}{$\begin{array}{c}\text { ICT's Role in } \\
\text { Price } \\
\text { Determination }\end{array}$} \\
\hline & Mobile & Internet & Apps & & & \\
\hline Age & - & - & - & - & - & + \\
\hline Education & + & + & + & + & + & + \\
\hline Farming experience & - & - & - & - & - & - \\
\hline Distance from extension office & - & - & - & - & - & - \\
\hline Distance from road & + & + & + & + & + & + \\
\hline
\end{tabular}

\section{Results and Discussion}

Three main stages along VC i.e., production, intermediary trade, and P\&Es were analyzed in this study. The following sub-sections showed current status of each stage, ICT use, factors influencing ICT use, and challenges and weaknesses faced.

\subsection{Citrus Production Stage}

The production stage included orchards establishment, cultural practices, irrigation, pest and disease control, and fertilization etc., which was dominated by growers and contractors. The majority of growers $(84.3 \%)$ preferred to sell their harvesting rights (see Table 3 ) because they wanted to lower the risks due to lack of labor, finance and market information. After signing the pre-harvest contract, growers and contractors together manage orchards $(91.7 \%)$ and growers were usually responsible for labor. The contractors always paid for inputs expenditure as well as organized harvesting, grading, transportation and marketing. They have determined orchard purchase price based on several factors including number of trees per hectare, number of fruits per tree, fruit weight and appearance, orchard general appearance, expected A-grade, and B-grade yield (A-grade is zero tolerance to damaged outer appearance, usually for export or high-end domestic market in big cities. B-grade has no standard on size and weight, usually sold in domestic markets in medium and low-income areas). One of major structural deficiencies at the production stage was that growers did not have much information about the market. Only $14.9 \%$ of them produced international quality-oriented products. Almost $71.9 \%$ of them did not care about product destination because they had weak awareness of quality standards and were unable to meet the high-end market demand.

Table 3. Grower's orchard contracting system and orientation to consumer markets.

\begin{tabular}{cc}
\hline Parameters & Percentage \\
\hline Sell orchard to contractors & $84.3 \%$ \\
Sell orchard to P\&Es & $13.2 \%$ \\
Sell orchards at fruiting stage & $82.2 \%$ \\
Sell orchard at ripening stage & $15.7 \%$ \\
Orchard management by both contractors and growers & $91.7 \%$ \\
Lack of knowledge of destination of product & $71.9 \%$ \\
International quality-oriented growers & $14.9 \%$ \\
\hline
\end{tabular}


ICT use at production stage. The important sources of information at production stage were mobile phone $(79.3 \%)$, private companies $(44.6 \%)$, internet $(41.3 \%)$, extension department $(24.8 \%)$, TV $(18.2 \%)$, and agricultural helpline $(10.7 \%)$. About $28.9 \%$ of growers were members of online discussion forums on Facebook or WhatsApp. These forums were established by progressive growers where they share experiences, production technologies, solutions for problems, and market trends etc.

For growers, the number of times they used ICT per month during VC active period was used to measure level of ICT use at each stage, mobile, internet and apps separately. In the case of mobile, $15.6 \%$ were non-users, $44.6 \%$ were low users, $28.1 \%$ were medium users and $11.6 \%$ were high users. As for internet, about $62 \%$ were non-users, $9.9 \%$ were low users, $19.8 \%$ were medium users, and only $8.3 \%$ were high users. App use was similar to the internet with $72.7 \%$ of non-users, $5 \%$ of low users, $15.7 \%$ of medium users and $6.6 \%$ of high users.

As mentioned earlier, a logit model was built to identify the factors influencing the growers' use of ICT tools, their strength, and direction of influence. The description of dependent and independent variables was given below in Table 4.

Table 4. Descriptive statistics of variables used in model.

\begin{tabular}{ccccc}
\hline Characteristics & Mean & Minimum & Maximum & Std. Deviation \\
\hline Age (years) & 45.17 & 24 & 73 & 12.797 \\
Education (years) & 11.83 & 0 & 22 & 4.435 \\
Farming experience (years) & 16.84 & 2 & 50 & 11.939 \\
Landholding (acre) & 29.19 & 3 & 200 & 37.474 \\
Distance from local market $(\mathrm{km})$ & 15.58 & 1 & 50 & 11.267 \\
Distance from extension office $(\mathrm{km})$ & 15.02 & 1 & 45 & 10.848 \\
Distance from metal road $(\mathrm{km})$ & 1.52 & 0 & 7 & 1.844 \\
Use of mobile phone & 0.85 & 0 & 1 & 0.357 \\
Use of internet & 0.44 & 0 & 1 & 0.498 \\
Use of apps & 0.34 & 0 & 1 & 0.475 \\
ICT's role in price determination & 0.79 & 0 & 1 & 0.407 \\
Willingness to invest in ICT & 0.82 & 0 & 1 & 0.387 \\
Membership of the online network & 0.29 & 0 & 1 & 0.455 \\
\hline
\end{tabular}

The mean age of respondents was 45 years representing that the majority of growers were at active age. As shown in Table 5, age had significant positive or negative effect on use of ICT. More specifically, odd ratios were $0.938,0.93,1.078,0.933$ and 1.051 respectively which showed that one-year increase in age, the odds ratio of membership of online networks and ICT's role in price determination increased by $7.8 \%$ and $5.1 \%$, respectively, and the odds ratio of internet, apps and the willingness to invest in ICT decreased by $6.2 \%, 7.0 \%$ and $6.7 \%$, respectively. In accordance with the findings of Jan et al. [28], on the one hand, age had the positive effect as older growers, as they could better understand advantage of modern technology, on the other hand, they may be risk-averse and less likely to use modern technology. Furthermore, this negative effect might be due to prejudice towards ICT as the entertainment tool.

Education was also very important for ICT use. About $4.1 \%$ of growers were illiterate, $1.7 \%$ had primary education, $6.6 \%$ had middle education, $24.8 \%$ finished high school, $43.8 \%$ had college education, and 19\% had university education. This showed that the majority of growers had high school or above education (mean education is 11.83). They were most likely to use ICT as education was an important factor in technology adoption and use [29]. More specifically, the odds ratio is $1.176,1.350,1.380,1.017,1.185$ and 1.141 respectively, which shown that with one-year increase in education, the odds ratio of mobile, internet use, apps use, willingness to invest in ICT, membership of online networks and role of ICT in price determination increased by $18 \%, 35 \%, 38 \%, 1.7 \%, 18.5 \%$ and $14.1 \%$, respectively.

Farming experience was negatively related to ICT use but the effect was not significant except the willingness to invest to obtain ICT. The reason might be that growers who had higher 
farming experience were likely to use their own knowledge rather than using ICT to obtain new agricultural information.

Landholding was also an important determinant of technology adoption as growers who had more land were likely to use ICT. Table 5 showed that landholding (mean 29.19) had only a significant impact on willingness to invest in ICT tools with a positive sign. This result was in accordance with Jan et al. [28] as they argued that respondents with more land were expected to have high income and likely to adopt the technology.

Table 5. Results of logit analysis of influencing factors of ICT use.

\begin{tabular}{|c|c|c|c|c|c|c|}
\hline \multirow[t]{2}{*}{ Variables } & \multicolumn{3}{|c|}{$\begin{array}{l}\text { ICT Tools to Obtain } \\
\text { Agriculture Information }\end{array}$} & \multirow{2}{*}{$\begin{array}{c}\text { Willingness } \\
\text { to Invest in } \\
\text { ICT }\end{array}$} & \multirow{2}{*}{$\begin{array}{c}\text { Membership } \\
\text { of Online } \\
\text { Network }\end{array}$} & \multirow{2}{*}{$\begin{array}{l}\text { ICT's Role in } \\
\text { Orchard Price } \\
\text { Determination }\end{array}$} \\
\hline & Mobile & Internet & Apps & & & \\
\hline Age & $\begin{array}{c}0.031 \\
(1.032)\end{array}$ & $\begin{array}{l}-0.064^{* * *} \\
(0.938)\end{array}$ & $\begin{array}{c}-0.067^{* * *} \\
(0.93)\end{array}$ & $\begin{array}{l}0.075^{* *} \\
(1.078)\end{array}$ & $\begin{array}{c}-0.069^{* * *} \\
(0.933)\end{array}$ & $\begin{array}{l}0.049^{*} \\
(1.051)\end{array}$ \\
\hline Education & $\begin{array}{l}0.162^{* *} \\
(1.176)\end{array}$ & $\begin{array}{c}0.300^{* * *} \\
(1.350)\end{array}$ & $\begin{array}{l}0.322 * * * \\
(1.38)\end{array}$ & $\begin{array}{c}0.017 \\
(1.017)\end{array}$ & $\begin{array}{c}0.169^{* * *} \\
(1.185)\end{array}$ & $\begin{array}{l}0.132 * \\
(1.141)\end{array}$ \\
\hline Farming experience & $\begin{array}{l}-0.013 \\
(0.987)\end{array}$ & $\begin{array}{l}-0.018 \\
(0.982) \\
\end{array}$ & $\begin{array}{c}-0.001 \\
(0.99) \\
\end{array}$ & $\begin{array}{c}-0.096^{* * *} \\
(0.909)\end{array}$ & $\begin{array}{c}0.001 \\
(1.001) \\
\end{array}$ & $\begin{array}{c}0.025 \\
(1.025) \\
\end{array}$ \\
\hline Landholding & $\begin{array}{c}0.014 \\
(1.015)\end{array}$ & $\begin{array}{l}-0.004 \\
(0.996)\end{array}$ & $\begin{array}{c}-0.006 \\
(0.99)\end{array}$ & $\begin{array}{l}0.024^{*} \\
(1.024)\end{array}$ & $\begin{array}{l}-0.012 \\
(0.988)\end{array}$ & $\begin{array}{c}0.011 \\
(1.012)\end{array}$ \\
\hline $\begin{array}{l}\text { Farm distance from } \\
\text { local market }\end{array}$ & $\begin{array}{c}0.274^{* * *} \\
(1.315)\end{array}$ & $\begin{array}{c}0.029 \\
(1.030)\end{array}$ & $\begin{array}{l}0.061 \\
(1.06)\end{array}$ & $\begin{array}{c}0.047 \\
(1.048)\end{array}$ & $\begin{array}{c}0.062 \\
(1.064)\end{array}$ & $\begin{array}{l}0.181 * * \\
(1.198)\end{array}$ \\
\hline $\begin{array}{l}\text { Farm distance from } \\
\text { extension office }\end{array}$ & $\begin{array}{l}-0.070 \\
(0.932)\end{array}$ & $\begin{array}{l}-0.045 \\
(0.956)\end{array}$ & $\begin{array}{c}-0.072 \\
(0.93)\end{array}$ & $\begin{array}{l}-0.008 \\
(0.992)\end{array}$ & $\begin{array}{c}-0.087^{* *} \\
(0.917)\end{array}$ & $\begin{array}{l}-0.132 * \\
(0.876)\end{array}$ \\
\hline $\begin{array}{l}\text { Farm distance from } \\
\text { metal road }\end{array}$ & $\begin{array}{l}-0.809^{* * *} \\
(0.445)\end{array}$ & $\begin{array}{l}-0.120 \\
(0.887)\end{array}$ & $\begin{array}{c}-0.115 \\
(0.89)\end{array}$ & $\begin{array}{l}-0.163 \\
(0.849)\end{array}$ & $\begin{array}{l}-0.260 \\
(0.771)\end{array}$ & $\begin{array}{c}-0.627^{* * *} \\
(0.534)\end{array}$ \\
\hline
\end{tabular}

Farm distance from the local market also had significant positive influence on use of mobile and ICT's role in price determination as shown in Table 5. This might be because growers who lived far from market were more likely to use mobile to obtain agriculture and price information. Ahsanuzzaman [30] also argued that the farther farmers were from the town center (market), the more likely they adopted ICT tools.

The farm distance from the extension office had significant negative effects on membership of online network and ICT's role in price determination. Farm distance from the road also had significant negative effects on mobile use and ICT's role in price determination as shown in Table 5. These results were in contrast to our expectation and probably the reason was that remote areas were likely to have poor physical infrastructure such as no internet access, which might result in growers lacking ICT awareness and not realizing what ICT can offer.

\subsection{Citrus Intermediary Trade}

The main stakeholders along citrus intermediary trade were contractors, commission agents, and wholesalers. After harvesting and grading, contractors transported citrus to fruit markets of Sargodha district and other provincial markets of Karachi, Quetta, Peshawar and Lahore. About 76\% of contractors reported they sold produce to commission agents only, while $24 \%$ reported they sold produce through P\&Es and commission agents. In detail, A-grade citrus were usually sold to P\&Es and the rest of the fruits were sold through commission agents. The commission agents reported that they sold products to wholesalers or directly to retailers. Then wholesalers sold the produce to retailers. The powerful stakeholder in citrus intermediary trade was commission agent which governed the whole process. The offices of commission agents were located in the central fruit market where fruit is sold in an open auction (before harvesting each year there is a meeting between growers and P\&Es associations and they decide a reference price and float around that price). The role of commission agents was to help actors make a deal such as contractors and wholesalers and they 
take 4-6\% (sometimes even more than $6 \%$ ) from citrus sales. Commission agents usually finance the contractors to buy the orchards with land or vehicle registration papers as mortgage.

ICT use during intermediary trade. The majority of respondents in the intermediary trade were below 45 years old and at active age (mean age of contractors 46.1, commission agents 36.7 , and wholesalers 37.8 years). In the case of education, majority of the contractors and wholesalers had education below middle school and commission agents had high school or above education. Most intermediaries (100\% of contractors and commission agents; $89.7 \%$ of wholesalers) used mobile phone to obtain trade-related information as depicted in Table 6 . This was because a mobile phone was the easiest way to convey price and market information even though they were less educated. The internet use of intermediaries was relatively lower with $32 \%$ of contractors, $7.4 \%$ of commission agents, and $10.3 \%$ of wholesalers. Specifically, as depicted in Figure 4, $68 \%$ of contractors were high users of mobile, $20 \%$ are high users of internet and no contractors used apps. About $96.3 \%$ of commission agents are high users of mobile phones, $92.6 \%$ were non-users of internet, and no commission agents used apps. About $66.7 \%$ of wholesalers were high users of mobile, $94.9 \%$ were non-users of internet and no wholesaler used apps. There was high use of mobile phone but limited use of internet and apps along intermediary trade.

Intermediaries do not participate in online discussion forums, which made information sharing difficult with other stakeholders and was a system weakness. Intermediaries preferred personal communication over group discussion because they thought that information sharing could affect their businesses. Other system weaknesses included lack of traceability, lack of storage facilities, lack of trust among intermediaries, and information asymmetry.

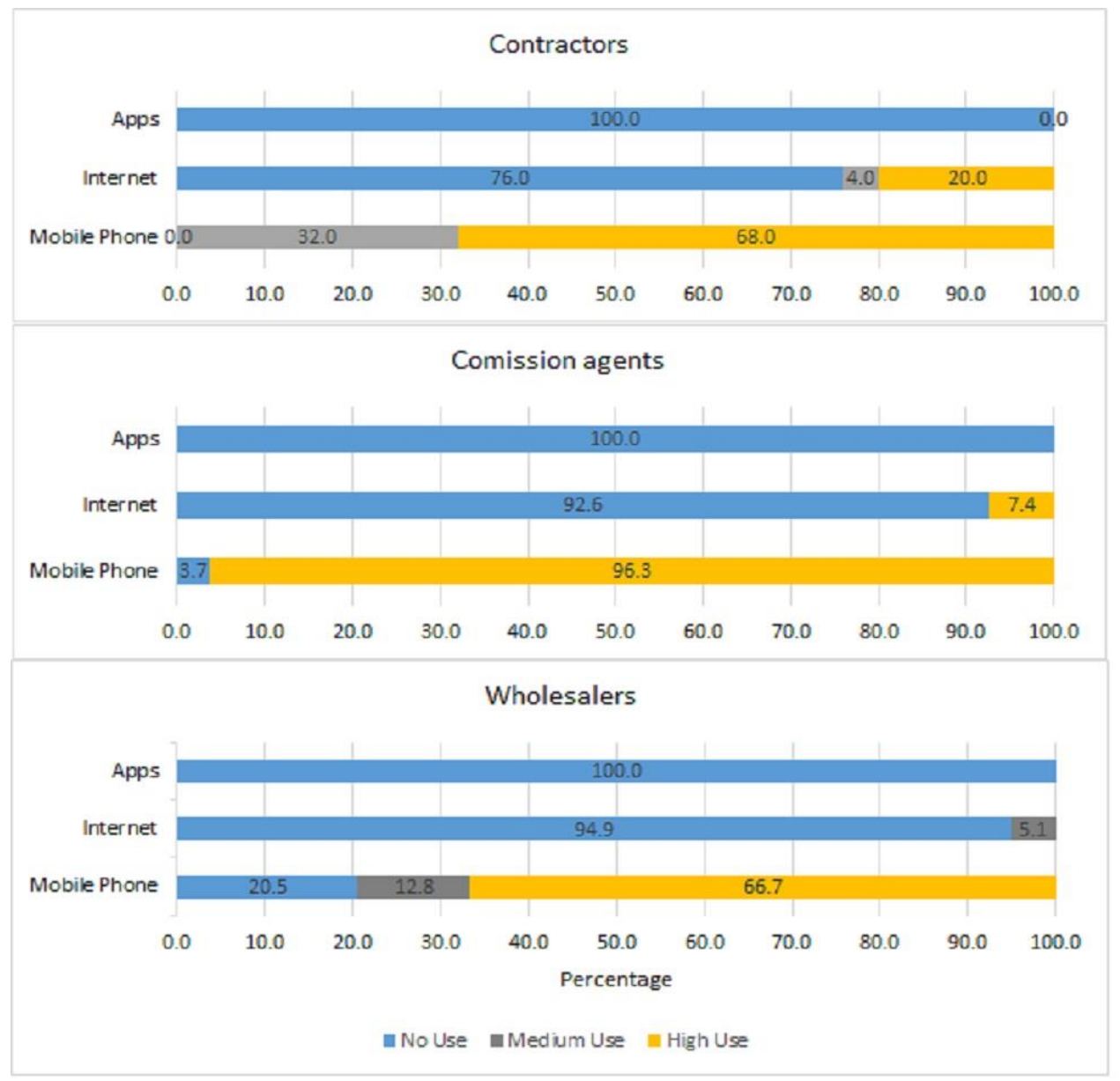

Figure 4. Level of use of ICT by stakeholders (per month). Low use =1-25, Medium Use = 26-100, High use $=101$-above. 


\subsection{Citrus Processing and Export Stage}

Interviews were conducted with managers coming from three leading processing and export enterprises. Enterprise-A had processed citrus after it received orders from buyers, about 26-150 metric ton citrus per day. It had exported $90 \%$ of its processed products and the remaining $10 \%$ were sold to high-end domestic market. Enterprise-B exported $70 \%$ of the processed product and the remaining 30\% were sold domestically. Enterprise-C exported $50 \%$ of processed product and sold $50 \%$ domestically.

The P\&Es sourced the harvesting rights directly from growers and hired specialized staffs to contract citrus orchards. Once the contract had been signed, the staff regularly visited the orchard and managed it together with growers. Enterprise-A had its own orchards as well as a contract for the orchards with growers. After processing and cold treatment (keeping them in cold storage for 3 days), then products were exported or sold in domestic markets. The P\&Es performed activities including sorting, washing, drying, waxing, packaging, and pre-cooling to add value to the citrus, and further meet the demands of export markets and high-income domestic markets. The products were packaged in food-graded corrugated packaging of 6,8 or $10 \mathrm{~kg}$ and labeled with brands.

Table 6. Demographic characteristics and sources of information being used along intermediary trade.

\begin{tabular}{|c|c|c|c|c|}
\hline & & \multicolumn{3}{|c|}{ Intermediary Trade } \\
\hline & & $\begin{array}{c}\text { Contractors \% } \\
\quad \mathrm{N}=25\end{array}$ & $\begin{array}{l}\text { Commission Agents } \\
\qquad \mathrm{N}=27\end{array}$ & $\begin{array}{c}\text { Wholesalers \% } \\
\mathrm{N}=39\end{array}$ \\
\hline \multicolumn{5}{|l|}{$\begin{array}{l}\text { Demographic } \\
\text { characteristics }\end{array}$} \\
\hline \multirow[t]{6}{*}{ Age } & below 25 & 0 & 3.7 & 17.5 \\
\hline & $26-35$ & 16.0 & 66.7 & 37.5 \\
\hline & $36-45$ & 40.0 & 18.5 & 22.5 \\
\hline & $46-55$ & 20.0 & 7.4 & 12.5 \\
\hline & $56-65$ & 24.0 & 0.0 & 2.5 \\
\hline & 65 or above & 0 & 3.7 & 5.0 \\
\hline \multirow[t]{6}{*}{ Education } & Illiterate & 36.0 & 0.0 & 43.6 \\
\hline & Primary & 16.0 & 0.0 & 20.5 \\
\hline & Middle & 8.0 & 11.1 & 17.9 \\
\hline & High School & 28.0 & 11.1 & 2.6 \\
\hline & College & 4.0 & 33.3 & 15.4 \\
\hline & University & 8.0 & 44.4 & 0.0 \\
\hline \multicolumn{5}{|l|}{ Sources of Information } \\
\hline Mobile & & 100 & 100 & 89.7 \\
\hline Internet & & 32 & 7.4 & 10.3 \\
\hline TV & & 24 & 25.9 & 0 \\
\hline Extension Department & & 16 & 0 & 0 \\
\hline Newspaper & & 0 & 0 & 5.1 \\
\hline Magazine & & 0 & 7.2 & 5.1 \\
\hline
\end{tabular}

The deficiencies identified in the citrus export sector were the failure of most of the exporters to meet the high food safety standards of European and Asian markets. That is why most exporters prefer Afghanistan and Gulf countries. The challenges for the citrus industry in Pakistan include increasing demand for seedless citrus and competition with Turkey and Egypt. Moreover, price fluctuation in international markets, currency exchange rates, and lack of insurance were important risks for citrus export. Pakistan's citrus industry faced a serious setback in 2016 because of price fluctuation in the international market.

ICT use at processing and export stage. P\&Es were significant users of the internet. It facilitated upstream communication, browsing, market research, knowledge of import tariffs and laws, quarantine and quality control laws, shipping and tracking, and feedback. Communication, collaboration and 
record keeping (orders and transactions) was done using emails. Social media apps such as WhatsApp were used to share fruit pictures and audio/video calls were used for negotiation with new buyers. Other apps include Skype and Facebook but their use is limited. During the inactive period, voice interactive messages are used to keep buyers in the loop. Exporters spend VC active time in research, planning, discussing future changes, market trends, value chain modifications, and exchange of ideas with buyers and other exporters keeping in view the need to avoid over-communication. Mobile phones were used for domestic communication with enterprise staffs, transporters, contractors, and growers. P\&Es also didn't take part in online discussion forums that makes information sharing difficult.

\subsection{Discussion}

This study has focused on ICT use along the citrus value chain, mainly at the production, intermediary trade, processing and export stages, factors influencing ICT use, digital divide among stakeholders, problems and challenges faced at different stages. This study has also provided an understanding of stakeholder's characteristics and their influence on value chain and other VC stakeholders. Figure 5 has summarized two product flows in the citrus value chain; one was more traditional with abundant intermediaries, and the other was export-oriented. It is a comprehensive picture to show stakeholders, activities, weaknesses, and challenges faced separately when following different product flows.

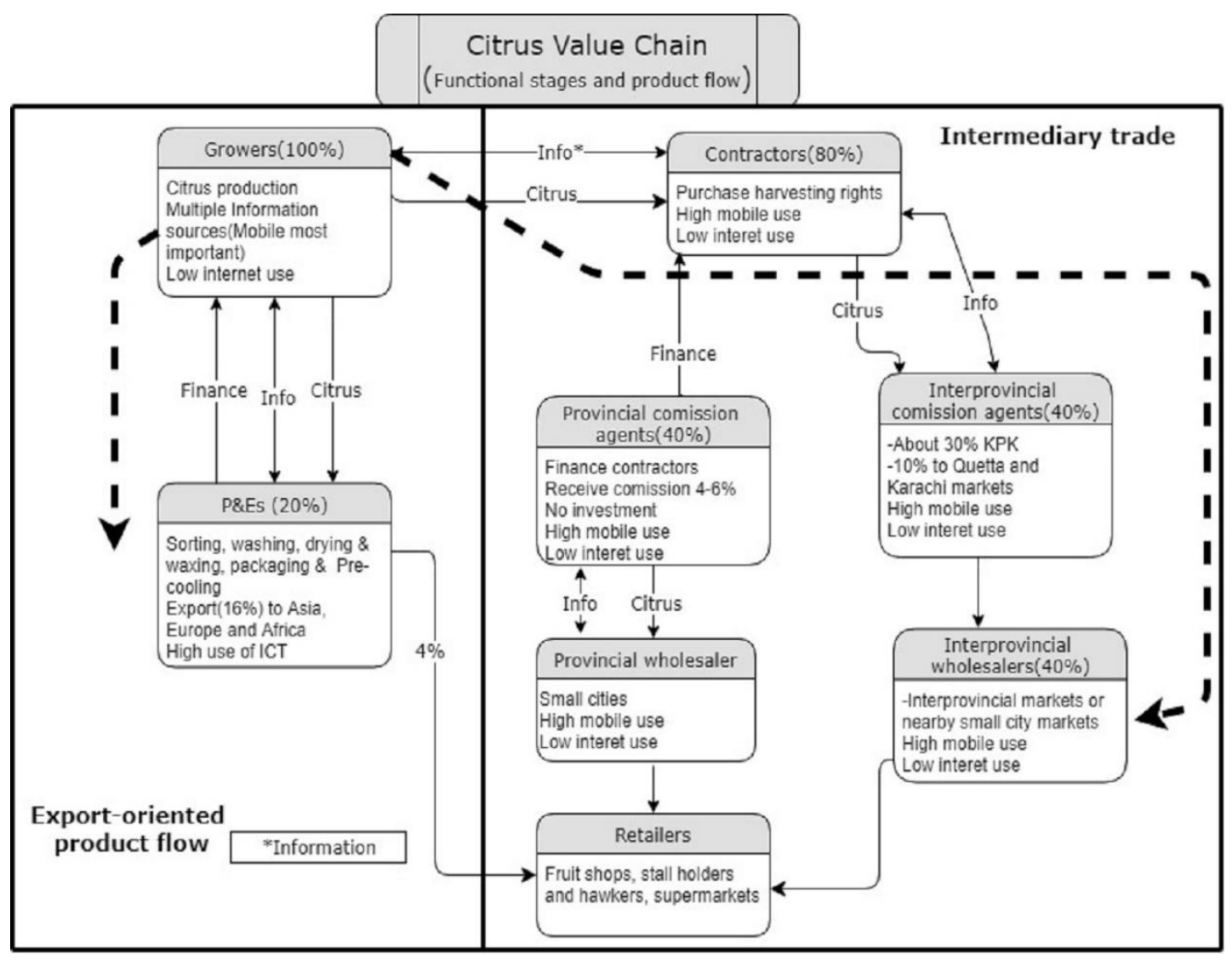

Figure 5. Flowchart of product flow and contribution of each node along different VCs operating and ICT usage at functional stages of citrus (Source: Prepared by Author).

Compared to other stakeholders, growers use multiple information sources to obtain information. At production stage, the mobile phone is the most important source of information and used to obtain information in a grower's social network. The second most important source of information is still farm 
visits by private input supplier companies who mainly provided agricultural information. Besides, the use of the internet to obtain information is very low. It is necessary to improve ICT-based information system to raise awareness, as growers are disconnected from the market and sell pre-harvesting rights to contractors. There is a need to build up knowledge portal, online discussion forums, and cross-function teams for all stakeholders along citrus value chain to improve the information system $[14,31]$.

The logit analysis has proved that education is the most important factor influencing ICT use at production stag. The majority of growers have an education above high school (English literate) and policies for capacity building on ICT (particularly for internet) can produce fruitful results. The model has also proved that growers with large landholdings is likely to invest in ICT because they are raising awareness of the potential advantages of ICT. Age has negative effects on the use of the internet or apps as well as participation in online network, which has indicated that youth can be the focus of policymakers in order to improve information system.

Among VC stakeholders, only growers and extension agents have online discussion forums. It should be a focus for policymakers to increase membership of these forums, which can reduce market risks, improve procedural justice, increase members' margins, and in the longer run contribute to sustainable agriculture and food systems. Stakeholders have different demands for information and researchers can play a role to identify the specific needs at each stage. For example, Pandey et al. [31] have identified several information requirements by growers regarding pest control, market linkages, insurance schemes, government schemes, subsidies and scientific agricultural practices. In particular, the lack of government market regulations leads to growers' reluctance to participate in the market.

There is a lack of value addition, food safety standards, marketing or management strategies and immediate returns along the intermediary trade [32]. The abundance of intermediaries is a burden of the distribution system and limit the capacity of producers to improve production as mentioned by Makokha et al. [33]. On the other hand, Alarcon et al. [32] have also argued that these markets are important because they offer cheap products for low-income people as well as livelihoods for intermediaries. Structural changes in these markets could have negative impact on food supply and livelihood, which should be considered carefully by policymakers. The problems associated with intermediary trade are the lack of traceability, lack of branding, lack of information sharing, and mutual trust. The government and research institutes always pay more attention to production and export rather than intermediary trade, even though it takes up much of the product flows.

There is a lack of information provision from extension department, non-governmental organizations (NGOs), research institutes, and universities along the intermediary trade. The main information tools for intermediaries are mobile phones. Despite having low education, they are high users of mobile as the United Nations Conference on Trade and Development (UNCTAD) [34] has reported that the mobile technology in developing countries have even surpassed the developed counties. The intermediaries are low users of the internet and unable to reap its potential advantages. The intermediary trade system could be the focus of policymakers to improve information availability. Research institutes, universities and Ministry of Commerce can use ICT as a tool for capacity building of intermediaries.

Few P\&E enterprises in Pakistan have certifications like Global-GAP (Global Good Agricultural Practices) and HACCP (Hazard Analysis and Critical Control Points), which is an important hindrance for Pakistani citrus to access the high-end markets of Europe and Asia. The enterprises require institutional supports to obtain food safety certifications and export their produces to other countries.

The internet has played the most important role in export, and is mainly used for building social networks and doing market research. Social networks can help exporters to increase value addition, retain the customers, and influence consumers' behaviors [35]. Exporters are high users of ICT but the uses of ICT are different in terms of enterprise internal system, trade volume, and access to high-end markets. This is a very important point but beyond the use of ICT, because education and research skills of exporters are key to reaping maximum advantages from ICT. As Liu \& Nath [36] 
mentioned, ICT access will not produce significant positive outcomes if ICT skills are not sufficiently high. Effective and timely price and product information transfer using ICT will help exporters to gain more market share.

As P\&Es have reported that they only process fresh fruits, there is a need for policymakers to encourage processed products such as citrus juice, pulp, dried citrus, and citrus tea. This will make sure the availability of citrus all year round in domestic as well as export markets and reduce the wastage of unsold products. Long-term policies also need to involve this kind of processed products into the food chain in order to improve their consumption.

The majority of stakeholders are high users of mobile, but for internet, there is wide digital divide among VC stakeholders as P\&Es are high users, followed by growers, and intermediaries are lowest users. This internet divide hinders the functioning of the internet-based information system.

\section{Conclusions}

Two VC product flows have been identified as intermediary and export-oriented flows. About $80 \%$ of citrus products were sold through intermediary flow and the main players are growers, contractors, commission agents and wholesalers. Export-oriented flow constitutes $20 \%$ of citrus and important players are growers and P\&Es. There is a high use of mobile and low use of internet and apps at the production and intermediary trade stages. The internet divide is wide among VC stakeholders. The results from the logit model shows that education, age and landholdings are the main factors influencing growers' ICT use, and growers who have more education are likely to use ICT. Also, human capital and skills rather than possessions of ICT are key to reaping maximum advantages from ICT. As observed, P\&Es are high users of ICT but there is a difference in their efficiencies. The weaknesses have been detected at various stages, including low use of internet in production and intermediary trade, lack of information sharing in intermediary trade, and lack of certifications at the export stage. It is necessary to improve the ICT-based information system to raise awareness, improve mutual trust, and increase market research to access the high-end market.

Author Contributions: The research framework, methodology and formal analysis were carried out together by all three authors. The data collection, original draft writing, editing, project administration was completed by M.W., and project implementation was supervised by N.F. and G.R.

Funding: This research has received the funding from Agricultural Science and Technology Innovation Program (ASTIP).

Acknowledgments: This research would not have been possible without the support of the Center for International Agricultural Research (CIAR) of Chinese Academy of Agricultural Sciences (CAAS). The authors also acknowledge with gratitude Muhammad Luqman, Basharat Ali Saleem, Ali Mujahid, Muhammad Israr, and Muhammad Riaz for their constant cooperation in data collection in Sargodha district and Muhammad Adeel Hassan in preparation of the GIS maps.

Conflicts of Interest: The authors declare no conflict of interest.

\section{References}

1. Sturgeon, T.; Zylberberg, E. The Global Information and Communications Technology Industry: Where Vietnam Fits in Global Value Chains; The World Bank: Washington, DC, USA, 2016.

2. Group of Twenty. Towards Food and Water Security: Fostering Sustainability, Advancing Innovation Berlin, Germany; G-20: Berlin, Germany, 2017. Available online: http://www.g20.utoronto.ca/2017/170122agriculture-en.pdf (accessed on 11 December 2018).

3. Svenfelt, A.; Zapico, J.L. Sustainable food systems with ICT? In Proceedings of the 4th International Conference ICT for Sustainability, 'Smart and Sustainable' (ICT4S 2016), Amsterdam, The Netherlands, 29 August-1 September 2016; pp. 194-201.

4. Krmac, E.V. Intelligent value chain networks: business intelligence and other ICT tools and technologies in supply/demand chains. In Supply Chain Management-New Perspectives; InTechOpen: London, UK, 2011.

5. Chopra, S.; Meindl, P. Supply chain management. Strategy, planning \& operation. In Das Summa Summarum des Management; Springer: Berlin, Germany, 2007; pp. 265-275. 
6. Maqbool, S.; Rafiq, M.; Imran, M.; Qadeer, A.; Abbas, T. Role of Information and Communication Technology in supply chain management to create competitive advantage: A literature base study. Int. J. Res. Commer. IT Manag. 2014. Available online: https://www.researchgate.net/publication/261793707_CREATING_COMPETITIVE_ ADVANTAGE_THROUGH_SUPPLY_CHAIN_MANAGEMENT (accessed on 11 December 2018).

7. Chisita, C.T. Knotting and networking agricultural information services through Web 2.0 to create an informed farming community: A case of Zimbabwe. In Proceedings of the World Library and Information Congress: 78th IFLA General Conference and Assembly, Helsinki, Finland, 11-17 August 2012; pp. 11-17.

8. De Silva, H.; Ratnadiwakara, D. Using ICT to Reduce Transaction Costs in Agriculture through Better Communication: A Case-Study from Sri Lanka; LIRNEasia: Colombo, Sri Lanka, 2008.

9. Zylberberg, E. Redefining Brazil's Role in Information and Communication Technology Global Value Chains. MIT-IPC Work. Pap. 2016. Available online: https://ipc.mit.edu/sites/default/files/documents/16-003.pdf (accessed on 11 December 2018 ).

10. Townsend, J.H. Digital Taxonomy for Sustainability; University of Southampton: Southampton, UK, 2015.

11. Chung, K.C.; Fleming, P.; Fleming, E. The impact of information and communication technology on international trade in fruit and vegetables in APEC. Asian-Pac. Econ. Lit. 2013, 27, 117-130. [CrossRef]

12. Ebner, H.; Manouselis, N.; Palmér, M.; Enoksson, F.; Palavitsinis, N.; Kastrantas, K.; Naeve, A. Learning object annotation for agricultural learning repositories. In Proceedings of the $2009 \mathrm{Ninth}$ IEEE International Conference on Advanced Learning Technologies, Riga, Latvia, 15-17 July 2009; pp. 438-442.

13. Qingfeng, Z. E-commerce key to modernized farming. China Daily Europe, 29 January 2018.

14. Siraj, M. Kinnow Value Chain Knowledge Gaps and ICT Prevalence in the Chain; CABI, South Asia: Rawalpindi, Pakistan, 2008.

15. International Telecommunication Union. Measuring the Information Society Report; International Telecommunication Union: Geneva, Switzerland, 2016.

16. Pakistan Bureau of Statistics. Pakistan Statistical Year Book; Pakistan Bureau of Statistics: Islamabad, Pakistan, 2016.

17. Broad Band Commission. The State of Broadband: Broadband Catalyzing Sustainable Development; United Nations: Geneva, Switzerland, 2016.

18. Hanif, U. Pakistan can improve ranking by adopting ICT. The Express Tribune, 25 March 2018.

19. Taylor, N.; Rushton, J. A Value Chain Approach to Animal Diseases Risk Management: Technical Foundations and Practical Framework for Field Application; FAO: Rome, Italy, 2011; Volume 4.

20. World Trade Organization. Pakistan Trade Profile; World Trade Organization: Geneva, Switzerland, 2016.

21. Naseer, M. Report on export of Kinnow; Trade Development Authority of Pakistan: Islamabad, Pakistan, 2010.

22. Sharif, M.; Farooq, U.; Malik, W.; Bashir, M. Citrus Marketing in Punjab: Constraints and Potential for Improvement [with Comments]. Pak. Dev. Rev. 2005, 44, 673-694. [CrossRef]

23. Siddique, M.I.; Garnevska, E. Citrus Value Chain(s): A Survey of Pakistan Citrus Industry; IntechOpen: London, UK, 2018.

24. Abbas, G. Pakistan exported record 370,000 tons of Kinnow in 2017-18. Pakistan Today, 6 June 2018.

25. Singh, M.; Marchis, A.; Capri, E. Greening, new frontiers for research and employment in the agro-food sector. Sci. Total Environ. 2014, 472, 437-443. [CrossRef] [PubMed]

26. Reardon, T.; Chen, K.; Minten, B.; Adriano, L. The Quiet Revolution in Staple Food Value Chains: Enter the Dragon, the Elephant, and the Tiger; Asian Development Bank: Mandaluyong, Philippines, 2012.

27. Metro. Fruits and Vegetables. Available online: https://www.metro.pk/product-worlds/fruits-vegetables (accessed on 11 December 2018).

28. Jan, I.; Ullah, S.; Akram, W.; Khan, N.P.; Asim, S.M.; Mahmood, Z.; Ahmad, M.N.; Ahmad, S.S. Adoption of improved cookstoves in Pakistan: A logit analysis. Biomass Bioenergy 2017, 103, 55-62. [CrossRef]

29. Ouedraogo, B. Household energy preferences for cooking in urban Ouagadougou, Burkina Faso. Energy Policy 2006, 34, 3787-3795. [CrossRef]

30. Ahsanuzzaman, A. Three Essays on Adoption and Impact of Agricultural Technology in Bangladesh; Virginia Tech: Blacksburg, VA, USA, 2015.

31. Pandey, M.; Sikka, B.; Panthari, S. ICT system for increasing efficiency of apple-value chain. In Proceedings of the National Seminar, Arunachal Pradesh, India, 9-11 April 2011. 
32. Alarcon, P.; Fèvre, E.M.; Murungi, M.K.; Muinde, P.; Akoko, J.; Dominguez-Salas, P.; Kiambi, S.; Ahmed, S.; Häsler, B.; Rushton, J. Mapping of beef, sheep and goat food systems in Nairobi-A framework for policy making and the identification of structural vulnerabilities and deficiencies. Agric. Syst. 2017, 152, 1-17. [CrossRef] [PubMed]

33. Makokha, S.; Witwer, M.; Monroy, L. Analysis of Incentives and Disincentives for Live Cattle in Kenya; Technical Notes Series, MAFAP, FAO, Rome (e Monitoring African Food and Agricultural Policies project-MAFAP); FAO: Rome, Italy, February 2013.

34. UNCTAD. Information Economy Report 2006; United Nations: New York, NY, USA; Geneva, Switzerland, 2006.

35. Mago, B.; Trivedi, P. Evidence of customers' perceptions toward the usage of social networking sites as e-business mechanism in UAE. Eur. Sci. J. ESJ 2014, 10. [CrossRef]

36. Liu, L.; Nath, H.K. Information and communications technology and trade in emerging market economies. Emerg. Mark. Financ. Trade 2013, 49, 67-87. [CrossRef]

(C) 2018 by the authors. Licensee MDPI, Basel, Switzerland. This article is an open access article distributed under the terms and conditions of the Creative Commons Attribution (CC BY) license (http://creativecommons.org/licenses/by/4.0/). 